\title{
Evaluating chlorophyll depletion in mitigation mussel cultivation at multiple scales
}

\author{
Jens Kjerulf Petersen ${ }^{1}$, Lars-Ove Loo $^{2}$, Daniel Taylor ${ }^{1, *}$ \\ ${ }^{1}$ Danish Shellfish Center, Technical University of Denmark, Øroddevej 80, 7900 Nykøbing Mors, Denmark \\ ${ }^{2}$ Department of Marine Sciences Tjarno, University of Gothenburg, 45296 Stromstad, Sweden
}

\begin{abstract}
Implementation of mussel culture for mitigating nutrient enrichment of coastal waters aims to optimize growth of mussels at production carrying capacity for maximum nutrient extraction. Simplified approaches for describing reductions in chlorophyll concentrations for the strategic deployment of mitigation units with regards to limited space and biophysical conditions can facilitate the proliferation of mitigation culture as a tool. Here we report data on measured chl a depletion at different scales in and around a mussel culture unit in western Sweden. A monitoring program was set up for a production period of 15 mo to characterize patterns of chl a depletion. The water column was almost permanently stratified, and concentrations of chl a were higher outside of the culture unit and autocorrelated within the unit by vertical and horizontal dimensions. Depletion of chl a within the culture unit during a focused sampling campaign period was negatively correlated with current velocity, greatest in the center of the unit (ca. $60 \%$ of ambient chl a concentrations) and lowest at the unit borders. Depletion was observed at the micro-scale within the boundary layer around the mussel aggregates, corresponding to a depletion gradient

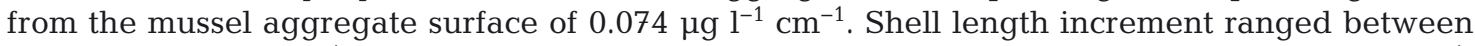
0.04 and $0.29 \mathrm{~mm} \mathrm{~d}^{-1}$ and specific growth rate ranged between 0 and $4.6 \%$ of dry weight $\mathrm{d}^{-1}$. A simple model was applied to evaluate scenarios of alternate farm configurations and fit to measured depletion. Model runs showed that the angle of incoming flow is important in a low-current regime (i.e. $<10 \mathrm{~cm} \mathrm{~s}^{-1}$ ), and orientating the culture unit in line with predominant current directions would allow for enhanced reduction of chl $a$.
\end{abstract}

KEY WORDS: Mussel cultivation - Eutrophication · Mitigation $\cdot$ Mytilus edulis $\cdot$ Chlorophyll depletion

\section{INTRODUCTION}

Anthropogenic enrichment of coastal waters has long been recognized as a principal driver of widespread degradation of global coastal marine ecosystems (Diaz et al. 2011). Eutrophication, coupled to population growth and industrialization, has been a persistent and growing phenomenon requiring concerted intervention at national and regional scales (Rabalais et al. 2009). In European coastal waters, eutrophication is common and widespread. A relatively high degree of policy aspirations and complex

*Corresponding author: dtay@aqua.dtu.dk implementation of mitigation strategies have been adopted in the attempt to control further impairment of coastal ecology (Savage et al. 2010). While it is the ambition of the Water Framework Directive (WFD, European Union [EU] directive 200/60/EC) to bring EU coastal waters up to a 'good' ecological status, in $2018,54 \%$ of all EU coastal waters still fell below this grade (EEA 2018). At the confluence of coastal environmental management and population expansion with concomitant expanding demand for higher dietary protein -it is ever more important to consider marine and terrestrial integration and synergistic

() The authors 2019. Open Access under Creative Commons by Attribution Licence. Use, distribution and reproduction are unrestricted. Authors and original publication must be credited. 
means to address coastal enrichment (Cottrell et al. 2018). Highly enriched aquatic environments experience ecological instability, requiring synergistic mitigative mechanisms for nutrient reduction that are economically tenable (Boesch 2002). These mechanisms are principally manifested through nutrient management programs that reduce or increase efficiency in nutrient application, or enhance nutrient sinks (Paerl 2009). In some regions, existing landbased abatement technologies have been implemented to an extent where increased establishment approaches the cost-value threshold with reduced efficacy (Petersen et al. 2016). Furthermore, existing nutrient loads in coastal waters are not limited to terrestrial or atmospheric sources. For example, the expansion of aquaculture of higher trophic species has contributed to increased nutrient loads in some regions (Sarà et al. 2011). With heightened scrutiny of coastal nutrient enrichment, demands for offsetting new nutrient emissions are becoming formalized in regulation (e.g. Danmarks Folketinget 2016).

Chlorophyll is a principal indicator in many marine ecological assessment models (Ferreira et al. 2011), and as a proxy for phytoplankton, the primary food source for bivalves. While the filtration of phytoplankton (or more generally, seston) has been recognized as an environmental service for some time (Officer et al. 1982), more recently, bivalve cultivation for systemic environmental services (namely, nutrient reduction) in productive waters has become a prominent focus (Gren et al. 2009, Petersen et al. 2014, 2016, 2019, Rose et al. 2014, Ferreira \& Bricker 2016). Emerging mussel cultivation practices which prioritize nutrient extraction in strategic locations have been termed 'mitigation mussel culture', aiming to maximize nitrogen $(\mathrm{N})$ removal from a given water body at the lowest possible operational costs. In contrast to mussel production for human consumption, where seston limitation can lead to uneven or suppressed growth, mitigation cultures aim to maximize nutrient extraction, which is often simply equivalent to maximizing biomass (i.e. filtration pressure) in a single growth cycle and harvesting before reaching 'market' size (Petersen et al. 2016). This cultivation practice disregards meat quality and homogeneity in size, instead using performance metrics such as total $\mathrm{N}$ yield, and basin-scale reduction in phytoplankton and sedimentation. Production strategies are designed to maximize the local impact, prioritizing reductions in chlorophyll concentrations over product quality. Thus, the ecological footprint of mitigation culture is larger by design. As mitigation cultures are designed to reduce basin-scale organic loads in eutrophic areas or in targeted areas as compensation for point sources (Danmarks Folketinget 2016), maximum phytoplankton depletion is generally considered an optimization inflection point, as long as uneven growth within a culture unit does not compromise overall extractive potential. Additionally, mitigation culture emphasizes operational cost reductions, which would otherwise be conducted to optimize product quality (i.e. optimal buoyancy compensation, thinning, socking, etc.).

Depletion describes integrated filtration. High densities of mussels may deplete food sources to such a level that production will be limited or growth will be anisotropically diminished. A consequence of maximizing biomass and filtration capacity is the depletion of phytoplankton and organic particles from the water column, potentially reducing light attenuation and scattering (Ibarra et al. 2012, Schröder et al. 2014), another primary objective of mitigation culture. Depletion will depend on not only stocking density or total biomass/filtering capacity of the mussels but will also depend on chemical and especially physical forcing (Stevens \& Petersen 2011). Thus, in a nutrient-rich, highly dynamic system with high current velocities, a depletion signal will be difficult to sense, and generally, mussels can be stocked densely. For practical reasons, mussel cultivation often takes place in protected areas with less physical forcing, and modeling studies have shown the importance of currents (e.g. O'Donncha et al. 2013) for depletion of seston in moderate physical energy regimes. Modeling of mussel cultivation is generally characterized by being very complex, involving many physiological parameters, or coarse by either ignoring physical forcing (Beadman et al. 2002) or running on an area level rather than a farm level (e.g. Rodhouse \& Roden 1987, Grant et al. 1998, Penney et al. 2001). As depletion and subsequently food limitation are driven by factors on scales that are influenced by farm-scale structures, it is important to evaluate food limitation as a function of culture configuration. As mitigation culture evolves into a water quality management tool, evaluating depletion at such scales can provide an indication of the local mitigation effect and potential for intensification (Nielsen et al. 2016).

To demonstrate depletion evaluation in mitigation culture, measurements are reported here of chl a depletion on 3 different scales inside and around a longline culture unit for production of blue mussels Mytulis edulis in a micro-tidal, eutrophic, lowcurrent environment in western Sweden: Ljungskile 
bight. The fjord system in the current study lies within the Skagerrak and Kattegat River Basin District, in which $82 \%$ of the constituent water bodies are failing to achieve 'good' ecological status (EEA 2018). Growth of mussels in the culture unit and application of a simple previously developed model (Incze \& Lutz 1980, Incze et al. 1981) were used to run scenarios of different configurations based on the measured results to assess potential maximal depletion in the study area. While a multitude of elaborate models have been developed for studying the interactions of aquaculture structures with hydrodynamics and particle distribution, in terms of accessibility and practical application in the strategic deployment of mitigation culture, simple approaches can offer sufficient estimations. We hypothesized that depletion at multiple scales would be directly impacted by hydrodynamics and farm orientation in a stratified micro-tidal fjord system and that these combined effects will be important for production characteristics and magnitude of the 'mitigation effect'.

\section{MATERIALS AND METHODS}

\subsection{Study site}

A longline culture unit situated in the bight of Ljungskile in the inner part of the Orust-Tjörn fjord system (Fig. 1) was used as the study site. In contrast to most fjords, the Orust-Tjörn fjord system is connected to the sea at both ends. Current measurements in different parts of the systems, though not at Ljungskile, indicate that circulation in the fjord system is net counterclockwise (mainly northward) and forced by the difference in steric height between the open ends (Björk et al. 2000). Salinity variations at the open ends give rise to density-driven currents, which may dominate the fjord exchange at large. Velocity measurements in different parts indicate that mean velocities are below $10 \mathrm{~cm} \mathrm{~s}^{-1}$. The tidal range is about $0.1 \mathrm{~m}$, salinity normally between 23 and $30 \mathrm{PSU}$, and temperature ranges from 15 to $20^{\circ} \mathrm{C}$ during summer in the surface layer to potentially weeks of ice cover during winter.

The culture unit studied consisted of 10 parallel longlines buoyed by plastic barrels, each line $300 \mathrm{~m}$ long and with ca. $1.6 \mathrm{~m}$ between each longline (Haamer 1997). This setup eliminates the requirement for additional buoyancy, an operational cost that mitigation culture aims to minimize. Woven polypropylene bands, $1 \mathrm{~mm}$ thick and $50 \mathrm{~mm}$ wide, were attached to the longlines in continuous loops

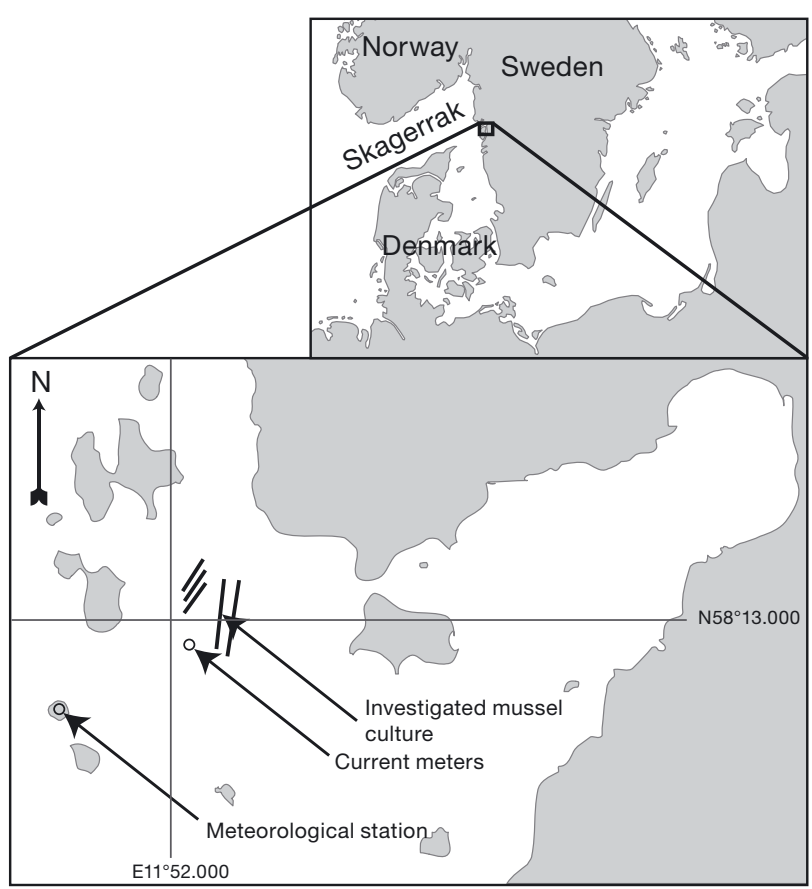

Fig. 1. Positions of the meteorological station and current meters in Ljungskile bight, western Sweden, during the campaign period. Each line on the lower map represents a mussel culture unit

extending from 1.5 to $7.5 \mathrm{~m}$ depth. The total length of the bands for all longlines was estimated to be $36 \mathrm{~km}$. The culture unit was deployed in late June 1999 and mussel spat was recruited during July and August.

\subsection{Monitoring program}

During the 15 mo monitoring period, 2 Ebro temperature loggers (Xylem Analytics) were attached to a longline at 1.5 (top) and $7 \mathrm{~m}$ (bottom) depths and set to $\log$ average temperature every $0.5 \mathrm{~h}$. In the same period and depths, water samples were taken 30 times outside and in the middle of the culture unit, most frequently between July and October (overall ca. every $2 \mathrm{wk}$ ) and with no sampling between December and February. Care was taken that the samples in the center of the culture were sampled between the 2 middle longlines. Three replicate water samples were taken on each occasion. Subsamples of $100 \mathrm{ml}$ were immediately filtered on a GF/C filter, and the filter was subsequently placed in $96 \%$ ethanol and kept in the dark for ca. $20 \mathrm{~h}$. Extracted chl a was analyzed with a Turner Designs 10AU fluorometer after correction for pheopigments (Holm-Hansen et al. 1965). Filtered water samples were stored at $-18^{\circ} \mathrm{C}$ until analysis. 


\subsection{Sampling campaign period}

A sampling campaign was performed to investigate chl a concentration patterns at multiple scales in relation to the dynamic physical environment over several days (July 10-20). A meteorological station was set up on a small island close to the culture unit (Fig. 1). Wind and gust speed, wind direction, solar radiation, and air temperature were measured continuously, and mean values were logged every 10 min with an Aanderaa AWS 2700 automatic weather station (Aanderaa Data Instruments). Aanderaa RCM9 current meters equipped with sensors for depth, temperature, salinity, current velocity and current direction were moored at 1.5 and $7.5 \mathrm{~m}$ depths and sampled mean values at 10 min intervals.

During the campaign period, procedures described in the monitoring program (see Section 2.2) were carried out daily and supplemented with casts measuring conductivity, temperature, and depth (CTD, ME Meerestechnik-Elektronik) at the same positions. Measurements of fluorescence were calibrated with water samples from the monitoring program. A drifting buoy with a drogue set at $3.5 \mathrm{~m}$ depth was deployed just before the start of the monitoring and was retrieved at the end of the sampling. Current velocity and direction were determined from differential GPS (D-GPS) positions at the start and end. On July 17, 17 CTD casts were taken at equal-interval positions (ca. $75 \mathrm{~m}$ ) longitudinally within the culture unit in order to detect potential depletion of chl a. On 4 occasions (July 12, 14, 15, 18), sampling was performed in the boundary layer around a mussel aggregate (i.e. the suspended mussel aggregates attached to spat collectors) using the siphon mimic technique (Petersen et al. 2008). Black plastic tubing (i.d. $3 \mathrm{~mm}$ ) was attached to a rod and protruded 0.1, 3, 10 and 20 $\mathrm{cm}$ from the surface of the rod in 4 directions orthogonally between each direction. The stick was mounted on the mussel band at a depth of $3.5 \mathrm{~m}$ using plastic strips and ensuring that the surface of the stick was on a par with the surface of the aggregate of mussels. In addition, a siphon mimic was attached to the mussel aggregate so that water could be sampled from the aggregate's interior (i.e. underneath mussels in proximity to the byssal matrix). Water was pumped to the surface using a peristaltic pump at a rate of $80 \mathrm{ml} \mathrm{min}^{-1}$ corresponding to the pumping rate of a mussel of $40-50 \mathrm{~mm}$ shell length (Riisgård 2001). Water samples were pre-filtered on an $80 \mu \mathrm{m}$ screen and analyzed for chl $a$ as described above (see Section 2.2). On each sampling occasion, triplicate water samples were taken within an hour.

\subsection{Mussels}

Mussels were sampled 10 times within the growth season and on each sampling occasion, 12 random samples were taken in each of 3 different depth strata (1.5-3.5, 3.5-5.5, and 5.5-7.5 m). The samples were collected with a round device $(10 \mathrm{~cm}$ high and $30 \mathrm{~cm}$ diameter) that can enclose a cluster of mussels on the mussel band and sever them from the band intact. All samples were frozen at $-18^{\circ} \mathrm{C}$ until processing. All mussels in each sample were counted and length measured. For a sub-sample of 60 mussels from each depth strata, length, body dry weight (DW), and shell dry weight $\left(48 \mathrm{~h}\right.$ at $\left.70^{\circ} \mathrm{C}\right)$ was determined. All numbers given per meter band include both sides of the band and are equivalent to a surface area of $0.1 \mathrm{~m}^{2}$.

\subsection{Model}

A simple algebraic model was applied to calculate the removal of chlorophyll as water passes through successive tiers of a mussel culture unit (Incze et al. 1981). In the model, we assume infinite available space so that capacity is defined by chlorophyll concentration and the size of the culture unit. The model assumes particle concentration homogeneity in each layer, that flow is normal to the face of each tier, clearance is constant, and that the flow through the culture unit is laminar.

The culture unit is represented by a depth $(h)$ of $6 \mathrm{~m}$, a width $(\mathrm{w})$ of $16 \mathrm{~m}(1.6 \mathrm{~m}$ between lines, $0.5 \mathrm{~m}$ between bands), and a length (l) of $300 \mathrm{~m}$, with a water surface area (a) and a face area $(A=h \cdot w)$, which 'faces' the current. For any system, the width and depth are constants for any solution of the model while the length can be determined by the outcome of the model via a series of finite sums involving the separate consideration of 1 'tier' of the culture unit at a time. The 'tier' consists of a 'line' of culture units extending the full width $(w)$ of the culture site (face area $A$ ). In this case, depletion rather than maximum length of a unit in Ljungskile is modeled. For the clearance component of the model, a density of 568 ind. $\mathrm{m}^{-2}$ (as measured in July 2000) and an individual clearance rate of $3.65 \mathrm{l} \mathrm{h}^{-1}$ estimated from the mean length of the animals in July 2000 (Riisgård 2001, Petersen et al. 2004) was assumed. Current velocities were derived from the measurements in the campaign period and were set to $\min .2 \mathrm{~cm} \mathrm{~s}^{-1}$ and max. $6 \mathrm{~cm} \mathrm{~s}^{-1}$. Chlorophyll concentrations were determined from measurements during the campaign period. 
The model was run with 2 different scenarios where $N_{k}$ indicates the depletion parameter in each scenario, and $n_{k}$ indicates depletion in each tier:

(I) $N_{k \text { perpendicular }}(\%)$ : In the first scenario, the 'tier 1' consists of the first longline if the current direction is perpendicular to the cultivation.

(II) $N_{k \text { longitudinal }}(\%)$ : In the second scenario, the 'tier 1' consists of the first culture unit from each of the longlines. Although the longlines are parallel (longitudinal) to the current, the tiers are perpendicular (Fig. 2).

To calculate depletion in chlorophyll concentration in any current direction, the results from Scenarios I and II are used. In Scenario I, depletion (\%) with a current direction perpendicular to the culture unit is:

$$
p=\left|100 \cdot \sin \left[\frac{\theta \cdot \pi}{180}\right]\right|
$$

where $\theta=$ the current angle $\left(^{\circ}\right)$ in relation to the culture, and $p=$ orthogonal proportion of flow. In Scenario II, depletion with a current direction longitudinal to the culture was calculated as:

$$
q=100-p
$$

where $q=$ longitudinal proportion of flow. 'Netchlorophyll' concentration $\left(n_{\theta k}, \%\right)$ after the cultivation unit at a specific current angle of incidence is thus:

$$
(\theta) n_{\theta k}=\left[\frac{n_{k \text { perpendicular }} \cdot p}{100}\right]+\left[\frac{n_{k \text { longitudinal }} \cdot q}{100}\right] \%
$$

where $n_{k}$ is the chlorophyll concentration entering tier $k$ in either scenario. The width of the culture unit used was $300 \mathrm{~m}$ in Scenario I and $12 \mathrm{~m}$ in Scenario II. The angle $\theta\left(^{\circ}\right)$ of water entering through the culture unit varied between $90^{\circ}$ and $180^{\circ}$ during the campaign period. The angle $90^{\circ}$ in the field corresponds to a longitudinal current and $180^{\circ}$ to a current perpendicular to the culture unit.

\subsection{Statistics}

Observations at the macro-scale, between the culture unit and ambient conditions, were analyzed by paired $t$-test, and by 2-way ANOVA when comparing seasonal differences and between top and bottom sections of the water column. Mussel growth metrics were compared by strata with 1-way ANOVA. Where significant differences were found, means were then compared by Tukey-Kramer's honestly significant difference (HSD) test. Data normality was assessed by the Shapiro-Wilk test, and equality of variance by the

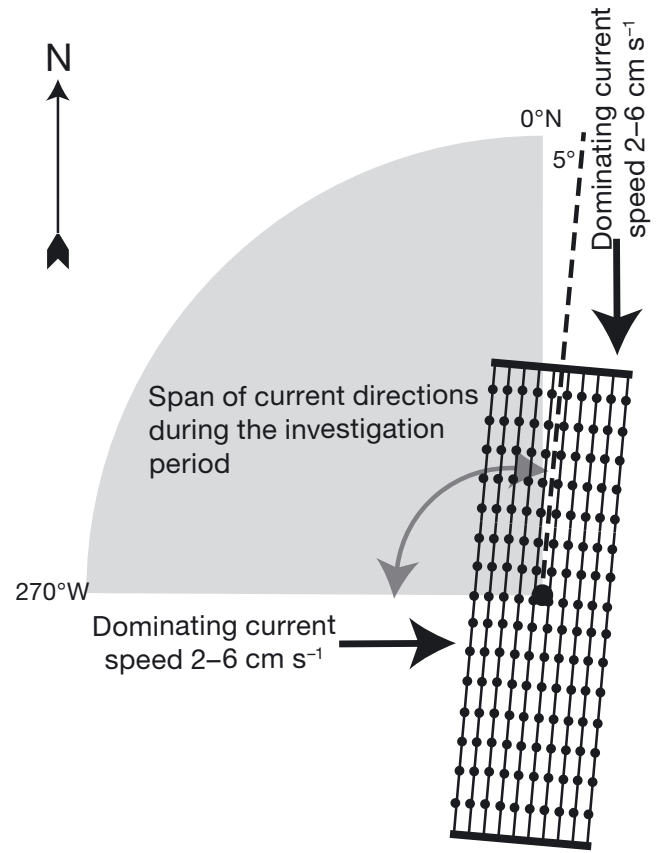

Fig. 2. Culture unit: 10 parallel longlines buoyed by floats (dots), each line $300 \mathrm{~m}$ long, and ca. $1.6 \mathrm{~m}$ between lines.

Grey shaded area: the dominating current directions

Bartlett test, where $\mathrm{p}>0.05$. Current velocities were linearly regressed against depletion at vertical strata.

As samples within the cultivation unit were not independent, meso-scale observations of chl a concentrations were analyzed spatially. Spatial autocorrelation was tested by constructing inverse spatial weight matrices and calculating Moran's $I$ in 2 dimensions:

$$
I=\frac{N}{S_{0}} \frac{\sum_{j=1}^{d_{1} \cdot d_{2}} \sum_{i=1}^{d_{1} \cdot d_{2}} \delta_{i j}\left(x_{j}-\bar{x}\right)\left(x_{i}-\bar{x}\right)}{\sum_{i=1}^{d_{1} \cdot d_{2}}\left(x_{i}-\bar{x}\right)^{2}}
$$

where $N=$ the number of points/cells with position $i, j ; x=$ chlorophyll concentration, $\bar{x}=$ mean chlorophyll concentration, $\delta_{i j}=$ spatial weights matrix, $d=$ geometric scale of each dimension in the $x$ or $y$ plane, and $S_{0}=$ sample variance. I falls between $-1<$ $I<1$, where zero indicates complete random distribution of values in space, negative values indicate regular dispersion of values, and positive values indicate clustering. A $z$-score and p-value can be calculated by determining the expected zero-value: $-1 /(N-1)$ (Moran 1950).

Local clustering of chl a values within the unit (meso-scale) was evaluated by calculating Getis-Ord $G_{i}^{*}$ at each point:

$$
G_{i}^{*}=\frac{\sum_{j=1}^{n} \delta_{i j} x_{j}-\bar{x} \sum_{j=1}^{n} \delta_{i j}}{S \sqrt{\frac{n \sum_{j=1}^{n} \delta_{i j}^{2}-\left(\sum_{j=1}^{n} \delta_{i j}\right)^{2}}{n-1}}}
$$


Corresponding $z$-scores and p-values are assigned at each point, indicating where high or low values are clustered together in space (Ord \& Getis 1995). To assess potential directional trends, sampling positions along the longitudinal axis were transformed to relative positions to the center of the unit, and thereafter, chl a concentrations were regressed against positions. Analyses were completed in R ( R Core Team 2017), and spatial statistics were calculated with the spdep package (Bivand \& Wong 2018).

\section{RESULTS}

\subsection{Monitoring program}

Water temperature varied during the production period from a minimum of $0.2^{\circ} \mathrm{C}$ in winter to $20.8^{\circ} \mathrm{C}$ in the summer (Fig. 3). Between the loggers situated at 1.5 and $7 \mathrm{~m}$ depth, the water column at the production site was generally stratified during the production period. Assuming a stratification threshold when change in temperature $(\Delta T)>0.3^{\circ} \mathrm{C}$, the water column was stratified for $70 \%$ of the time from August 1999 to the end of November 2000. The longest recorded period with a mixed water column was 5.7 $\mathrm{d}$ and the longest continuous period of stratification was $28 \mathrm{~d}$. If the criteria for stratification is set to $0.1^{\circ} \mathrm{C}$, then the water column could be considered stratified for $89 \%$ of the time and the longest period of mixing would have been $26 \mathrm{~h}$, and of stratification, $46 \mathrm{~d}$. Water quality data from the monitoring program is summarized in Table 1. Concentrations of chl a varied over the year, with lowest concentrations in win-

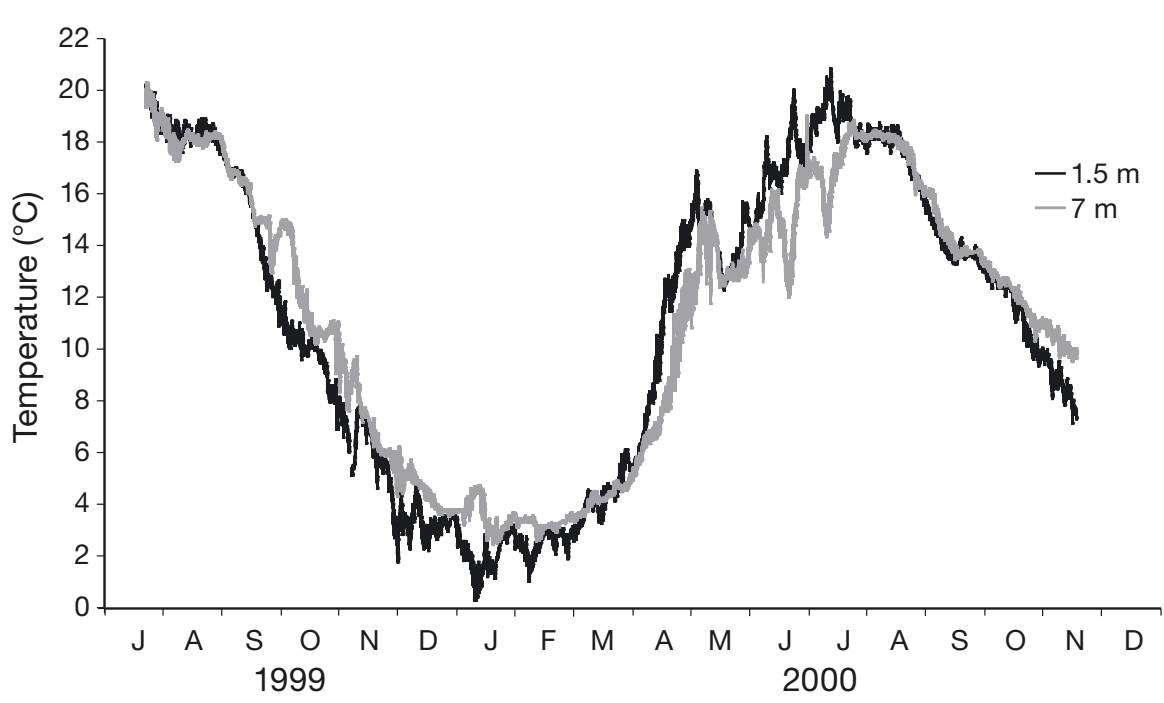

Fig. 3. Temperature at 2 depths $(1.5$ and $7 \mathrm{~m})$ in the center of the culture unit during a production period
Table 1. Concentration of chl a inside and outside the culture unit sampled in the production period Aug 1999 to Oct 2000 at 2 depths: top $(1.5 \mathrm{~m})$ and bottom $(7 \mathrm{~m})$

\begin{tabular}{|c|c|c|c|}
\hline & \multirow[b]{2}{*}{ Mean } & \multicolumn{2}{|c|}{$a\left(\mu g l^{-1}\right)-$} \\
\hline & & $\mathrm{SD}$ & Range \\
\hline Inside, top & 4.2 & 5.7 & $0.4-12.2$ \\
\hline Inside, bottom & 1.7 & 1.2 & $0.1-5.1$ \\
\hline Outside, top & 4.6 & 3.0 & $0.3-11.6$ \\
\hline Outside, bottom & 2.5 & 2.6 & $0.1-10.1$ \\
\hline
\end{tabular}

ter (Fig. 4), and were significantly different between top and bottom, both inside and outside the culture unit (2-way ANOVA, $\left.F_{2,288}=21.32, \mathrm{p}<0.0001\right)$. There was also a significant difference of chl a between the inside and outside of the culture unit (paired $t$-test, $t_{131}=2.469, \mathrm{p}=0.0147$ ). At $7 \mathrm{~m}$ depth, mean concentration in the middle of the culture unit was $77 \%$ of outside concentration, whereas the food depletion at $1.5 \mathrm{~m}$ was only $95 \%$ of the outside concentration.

On an annual basis, concentrations of chl a were around or just below $2 \mu \mathrm{g} \mathrm{l}^{-1}$ in winter and early spring, rising to values of ca. 6-10 $\mu \mathrm{g} \mathrm{l}^{-1}$ during the period May-September, and 4-6 $\mu \mathrm{g} \mathrm{l}^{-1}$ in the autumn. Lower chl a concentrations were observed in the bottom layer, compared to the top, but displayed the same annual pattern.

\subsection{Sampling campaign period}

During the campaign period, mean air temperature was $15.6 \pm 1.95^{\circ} \mathrm{C}$ (range: $10.2-20.9^{\circ} \mathrm{C}$ ), with mean wind speeds in the range of $0.2-10.9$ $\mathrm{m} \mathrm{s}^{-1}$, gusting up to $15.2 \mathrm{~m} \mathrm{~s}^{-1}$ in bursts, with an average speed for the entire study period of $3.9 \pm 1.9 \mathrm{~m} \mathrm{~s}^{-1}$. The water column was stratified with no mixing events between 1.5 and $7 \mathrm{~m}$ during the campaign period. The depth of the surface mixed layer was strongly and positively correlated to wind speed, but wind speed could not entirely explain the variation in depth of the layer ( $\mathrm{r}=0.77, \mathrm{p}=0.007, \mathrm{n}=13$ ). Temperature was on average $18.2 \pm$ $0.6^{\circ} \mathrm{C}$ at $1.5 \mathrm{~m}$ depth and $16.5 \pm 0.3^{\circ} \mathrm{C}$ at $7 \mathrm{~m}$, while conductivity was $27.8 \pm$ $0.9 \mathrm{mS} \mathrm{cm}^{-1}$ at $1.5 \mathrm{~m}$ and $31.6 \pm 0.8$ at $\mathrm{mS} \mathrm{cm} \mathrm{cm}^{-1}$ at $7 \mathrm{~m}$. Current velocity and direction were different at the 2 water levels during the campaign period 


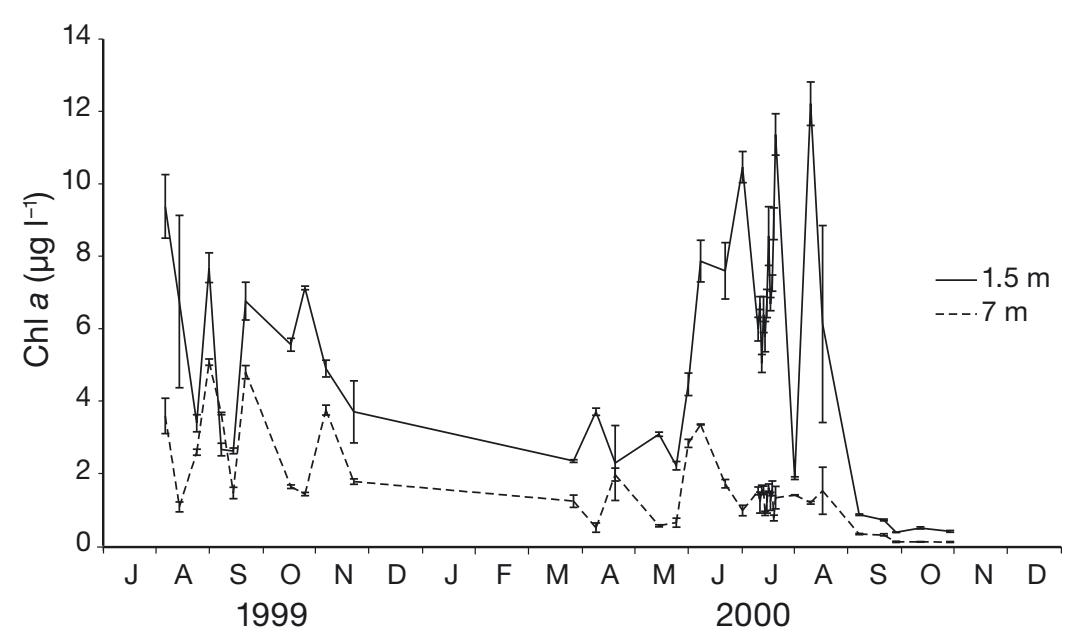

Fig. 4. Concentrations (mean $\pm \mathrm{SD}$ ) of chl $a$ at 2 depths $(1.5$ and $7 \mathrm{~m}$ ) in the center of the culture unit during a production period

(Fig. 5). From the daily CTD casts, 3 separate layers within $8 \mathrm{~m}$ of the water column could be delineated every day (upper, middle, lower). The depth extension of each layer varied between days. Concentrations of chl a were highest in the upper layer (5.97 \pm $\left.1.01 \mathrm{\mu g} \mathrm{l}^{-1}\right)$ relative to the middle $\left(2.85 \pm 1.26 \mathrm{gg} \mathrm{l}^{-1}\right)$ and lower layers $\left(1.1 \pm 0.39 \mu \mathrm{g} \mathrm{l}^{-1}\right)$.

Depletion of chl a could be detected on 3 levels and is reported as the measured relative proportion to the measured ambient (outside) conditions. On the macro-scale, comparing internal and external conditions of the culture unit, depletion was analyzed separately for the 3 layers detected in the CTD profiles.
Patterns of depletion of chl a in relation to current velocity was found to differ between layers. In the top layer, normally 1-3 $\mathrm{m}$ deep, depletion of chl a was minimal, with concentrations inside the unit between 80 and $100 \%$ of external concentrations. Depletion in the upper layer was correlated with current velocities measured with the current meter at $1.5 \mathrm{~m}$ $\left(y=0.87+0.019 x, R^{2}=0.35, p=0.034\right.$, $\mathrm{n}=13$; after removal of 2 outliers from the analysis: $y=0.83+0.025 x, \mathrm{R}^{2}=$ $0.61, \mathrm{p}=0.004, \mathrm{n}=11$; Fig. 6A). In the middle layer, concentrations of chl a ranged between 65 and $100 \%$ (mean: $81.8 \pm 11.34 \%$ ) of external concentrations and were correlated $(y=0.64+$ $0.047 x, \mathrm{R}^{2}=0.73, \mathrm{p}<0.001, \mathrm{n}=13$ ) to current velocity measured with the drifting buoy (Fig. 6B). There was no significant correlation $\left(y=0.73+0.047 x, R^{2}=0.13\right.$, $\mathrm{p}=0.22, \mathrm{n}=13$ ) between current velocity measured with the current meter at $7 \mathrm{~m}$ and depletion in the lower layer (Fig. 6C). Concentrations in the lower layer of chl $a$ inside the culture unit ranged between 63 and $100 \%$ (mean: $84.7 \pm 12.07 \%$ ) of external concentrations.

On the meso-scale within the culture unit, chl a depletion was detected in all layers, from near the upstream end of the culture unit, and with maximum depletion in the lower central part of the unit (57\% of
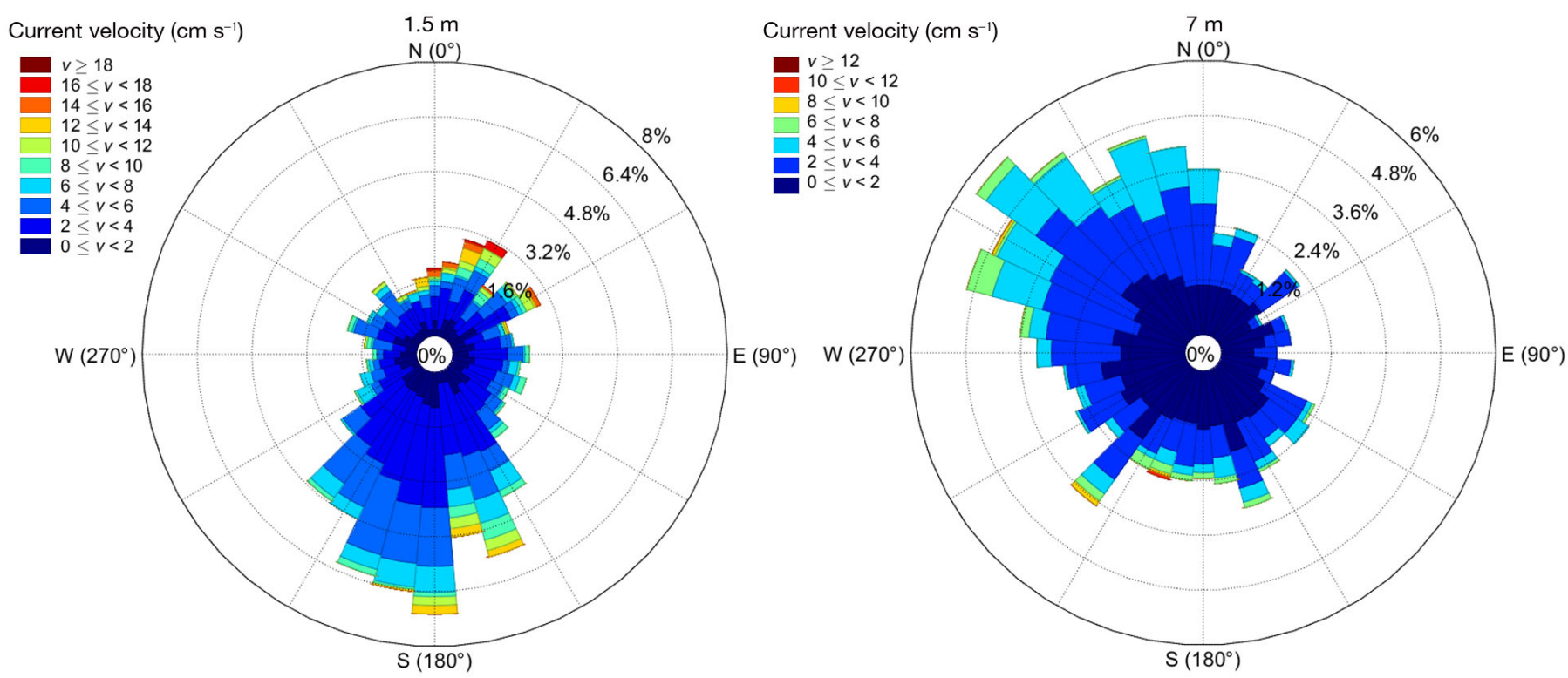

Fig. 5. Measured current velocities $(v)$ and frequencies of current direction at 1.5 and $7 \mathrm{~m}$ depths during the campaign period. Data plotted with Wind Rose package in Matlab 

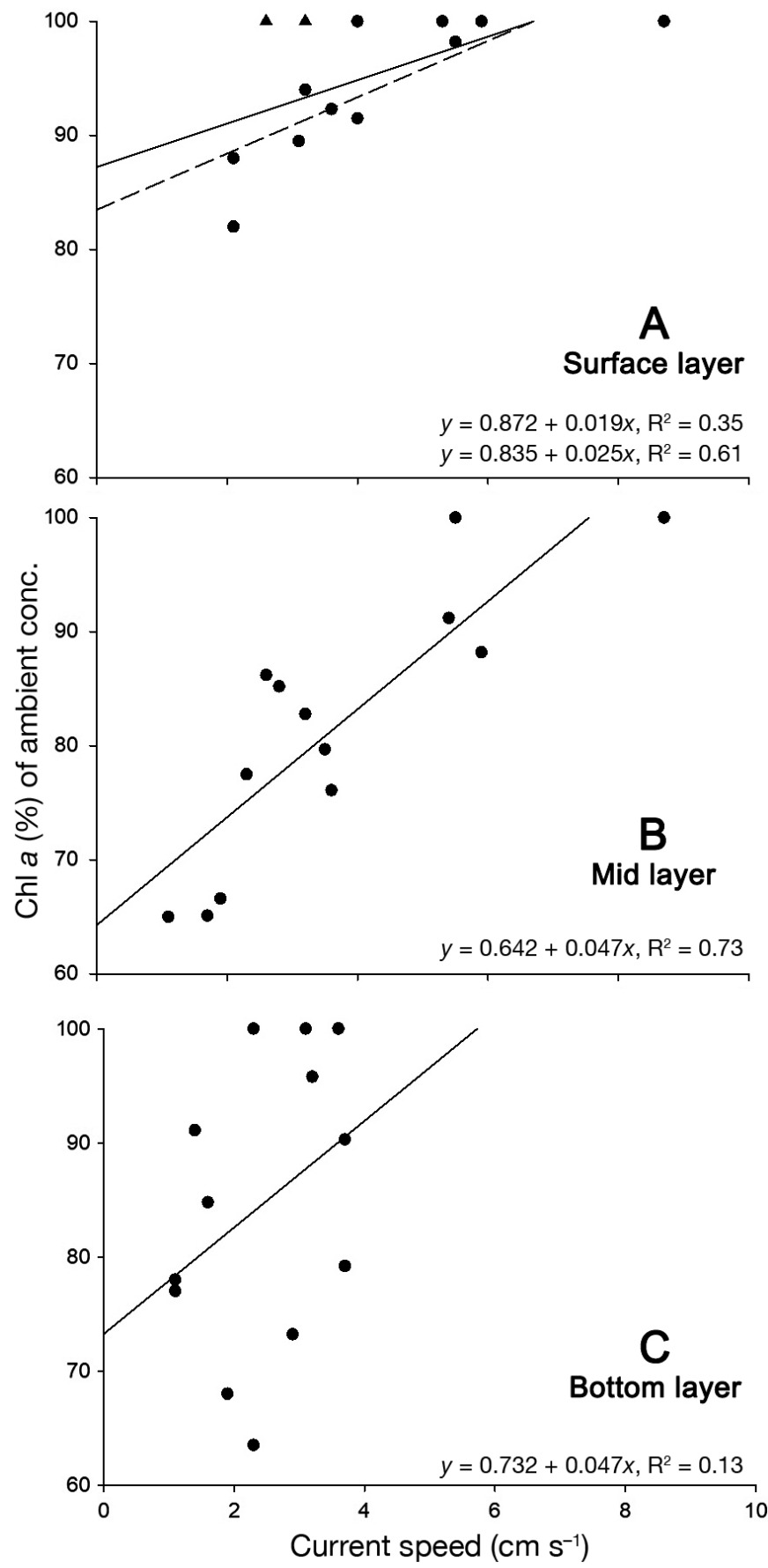

Fig. 6. Measured depletion of chl a as a function of current velocity in 3 depth layers: (A) surface, (B) middle, and (C) bottom. The 2 triangles in $(\mathrm{A})$ are excluded as outliers, as the depth of the top layer (1.3-1.4 m) was above the upper limit of the mussel bands (ca. $1.5 \mathrm{~m}$ ). Regression lines plotted for all points (solid line) and without outliers in (A) (dashed line)

ambient levels). Over the entire unit, there was significant positive autocorrelation in chl a concentrations (Moran's $I=0.58, \mathrm{p}<0.001$ ), indicating concentrations were not randomly distributed within the unit and clustering of values within the farm was positive. Clustering of high chl a values was positive in the upper layer $\left(1.25>G_{i}^{*}>2.5\right.$, significant at the upstream edge, $p<0.05)$, intermediate in the midsection $\left(-1.1>G_{i}^{*}>0.75\right)$, while clustering of low values was high in the lower layer $\left(-2.22>G_{i}^{*}>-0.72\right.$, significant in the upper to lower mid-sections of the farm, $\mathrm{p}<0.05$ ). Clustering of depletion rates was significant $(\mathrm{p}<0.05)$ at the upstream end, and within the middle layer, in the mid-sections. Linear regression of chl a concentrations by position exhibited significant negative correlation with the center of the unit ( $p<0.001)$. Depletion was most pronounced in the middle layer compared to the upper and bottom layers and in the longitudinal center of the unit (Fig. 7). Mean initial concentrations varied between layers, from $5.97 \pm 1.01 \mathrm{\mu g} \mathrm{l}^{-1}$ in the upper layer, $2.85 \pm 1.25 \mathrm{\mu g} \mathrm{l}^{-1}$ in the middle and $1.09 \pm 0.39 \mu \mathrm{g} \mathrm{l^{-1 }}$ in the lower.

On the micro-scale, considered around and inside the mussel aggregations, a chl a gradient towards the mussel band was observed on all measuring occasions and irrespective of orientation of the mimics. A representative example of gradients and average relative concentrations in reference to distance from the aggregates are shown in Fig. 8. In general, chl a levels inside the mussel aggregations $(-2 \mathrm{~cm})$ were often higher than on the surface $(0.1 \mathrm{~cm})$ of the aggregations, concurrent with proportionally higher concentrations of pheopigments. This suggests sampling detrital material in between the mussels confounds depletion analysis within aggregations; therefore, depletion was quantified from $0.1 \mathrm{~cm}$ and greater

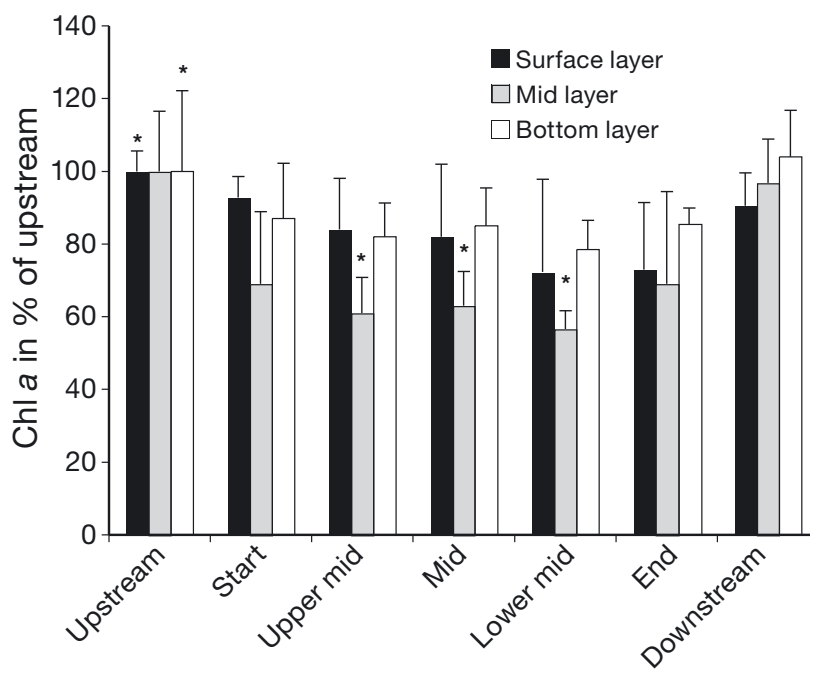

Fig. 7. Average (+SD) depletion of chl $a$ in 3 depth layers within a mussel culture unit measured on a single occasion. *Significant clustering of high or low depletion rates by Getis-Ord $G_{i}^{*}$ 

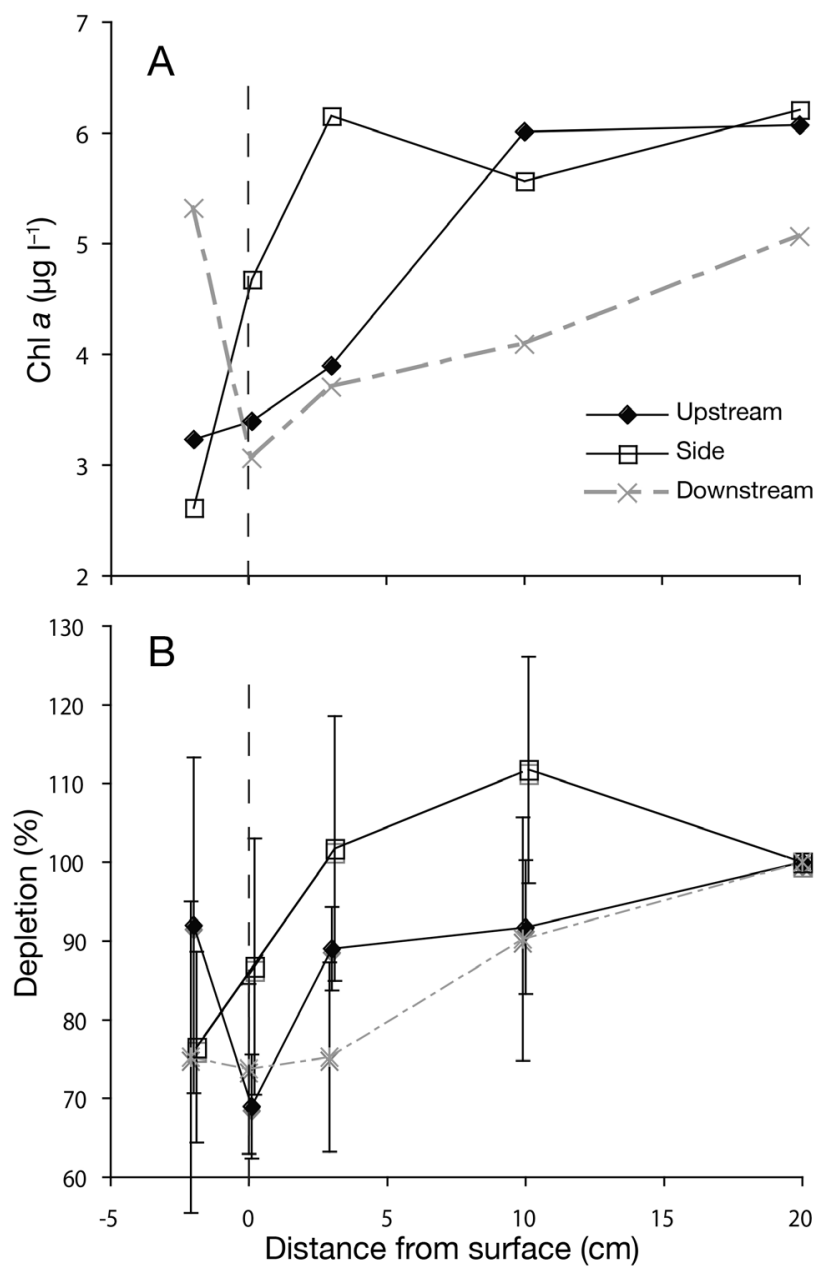

Fig. 8. Depletion of chl a measured in the boundary layer within centimeters from the mussel bands. Upstream: siphon mimic pointed against the flow; side: perpendicular to main flow; downstream: pointed in the flow direction. (A) Example of chlorophyll concentration patterns with distance from a mussel band; (B) average depletion using $20 \mathrm{~cm}$ as reference for 3 replicates on 4 different days. Dashed vertical line: surface of the mussel aggregate

distances. Average depletion from 20 to $0.1 \mathrm{~cm}$ from the surface of the mussel aggregations over 4 monitoring occasions, and all orientations of the mimics in relation to current direction, was $77 \pm 13 \%$. There was no clear relationship between depletion on the micro-scale and forcing parameters like wind speed or current velocity. The average slope of the linear relation between concentration of chl a (dependent variable) and distance from the mussel band (independent variable) was 0.21 , lending a concentration gradient in the $20 \mathrm{~cm}$ zone of $0.074 \mu \mathrm{g} \mathrm{l}^{-1} \mathrm{~cm}^{-1}$ at the time of study.

\subsection{Mussels}

Data on mussel abundance, length and DW of soft parts for 3 different depth strata during the production period are presented in Fig. 9. From August 1999 to October 2000, abundance decreased from ca. 2600 to ca. 500 ind. $\mathrm{m}^{-1}$, with the major decrease during winter. Decrease in numbers can be attributed to increased individual size, causing mussels to be squeezed off the mussel band ('self-thinning'), but also predation by eider ducks and starfish, as well as general/idiopathic mortality. Length increased from 12-13 $\mathrm{mm}$ in August to 58-59 $\mathrm{mm}$ in October, with the slowest length increment during winter. Individual DW increased to the greatest extent in the summer months. There were no significant differences in abundance or mean length of mussels in the last 3 sampling periods, but at all other occasions, abundance and mean length were significantly lowest in the top layer ( $\mathrm{p}<0.05$, ANOVA with Tukey-Kramer HSD post hoc test). There was significant difference between all depth strata in the final sampling of individual DW (top: $2.36 \pm 0.23 \mathrm{~g}$, mid: $1.84 \pm 0.14 \mathrm{~g}$, bottom: $2.15 \pm 0.27 \mathrm{~g}$ ). Significantly lower DW in the mid-layer in September was also observed (top: $1.64 \pm 0.12 \mathrm{~g}$, mid: $1.39 \pm 0.09 \mathrm{~g}$, bottom: $1.56 \pm$ $0.23 \mathrm{~g}$ ), diverging from other population parameter trends. At all previous sampling periods, no significant differences could be detected (ANOVA with Tukey-Kramer HSD post hoc test), indicating divergence in vertical growth patterns at the end of the summer. At all depths, extensive interspecific fouling was not observed, as mussels dominated the substrate.

Horizontal effects were analyzed by pooling data from the last 4 sampling periods, where depletion due to the high grazing potential of the adult mussels was expected to be the greatest. As mussel filtration capacity increases with size, and these periods were closer to the time of harvest, such data points would provide a better approximation of depletion-related growth asymmetry. Only data on length was analyzed, as this was the only parameter that could be appropriately discretized into different horizontal compartments. Significant difference between the outer longlines compared to mid longlines was found, with lower mean length in the center ( $t$-test, $\left.t_{33768}=9.854, \mathrm{p}<0.001\right)$. Analysis of vertical gradients exhibited significantly lower mean length in the top layer compared to the mid and bottom layer (1-way ANOVA, $\left.F_{2,33817}=30.633, \mathrm{p}<0.001\right)$. This difference was most pronounced in the central part of the culture unit. 


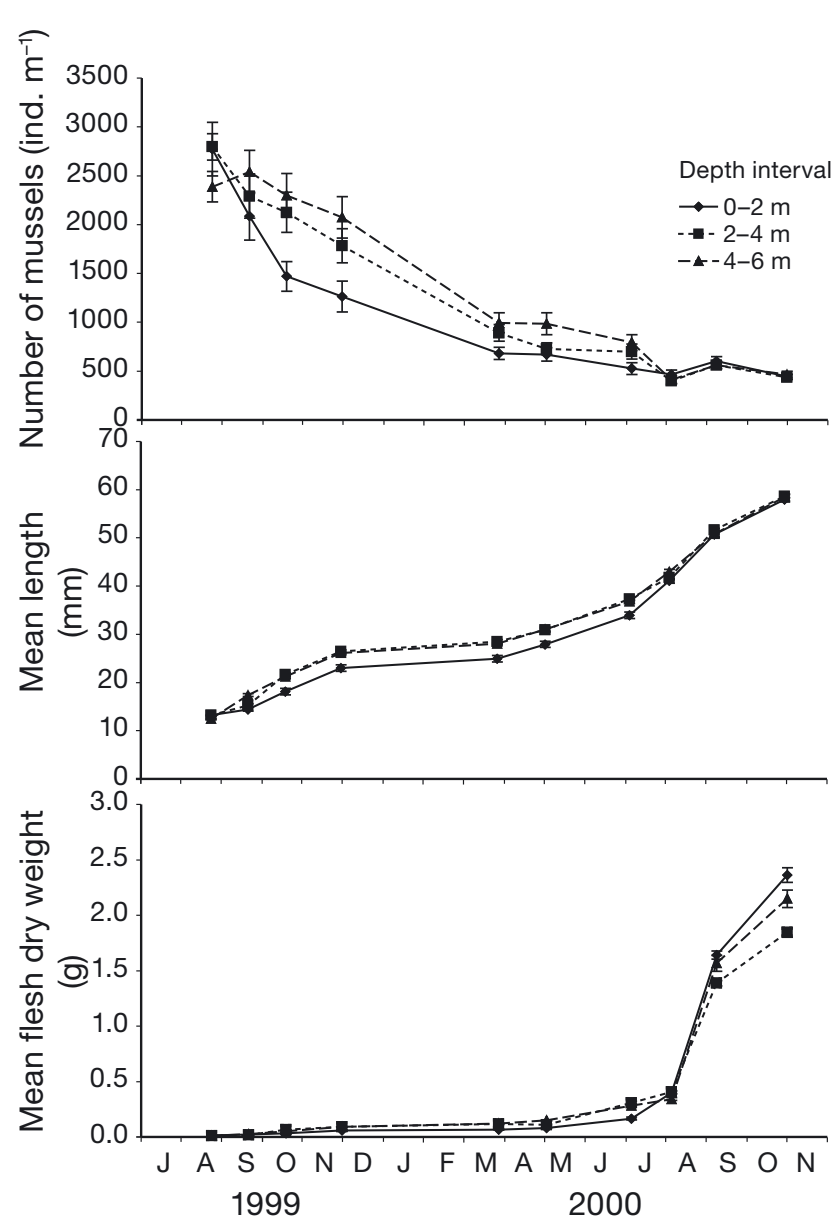

Fig. 9. Measured mean abundance, mean individual length and mean individual dry weight of body parts of mussels from Aug 1999 to Oct 2000

Total production of the culture unit was estimated to ca. 300 t, which corresponds well with the amount harvested (A. B. Scanfjord, mussle farmer, pers. comm.). Specific growth rate and length increment ranged between 0 and $4.6 \% \mathrm{~d}^{-1}$, and 0.04 and $0.29 \mathrm{~mm} \mathrm{~d}^{-1}$, respectively, with the highest growth rates in the summer and early autumn, and lowest growth in winter.

\subsection{Model}

The general input to the model was (1) micro-scale depletion of $70-90 \%$, (2) current directions $0-360^{\circ}$, with current directions in the campaign period between 270 and $360^{\circ}$, and (3) current velocities of 2$6 \mathrm{~cm} \mathrm{~s}^{-1}$, and a maximum current velocity of $17 \mathrm{~cm} \mathrm{~s}^{-1}$. The lowest potential depletion was $88 \%$ of the upstream concentration, corresponding to a current velocity of $17 \mathrm{~cm} \mathrm{~s}^{-1}$, a current direction of $270^{\circ}(\mathrm{W})$ and a micro-depletion of $90 \%$ of ambient conditions (Fig. 10). Maximum depletion (7\% of upstream con-

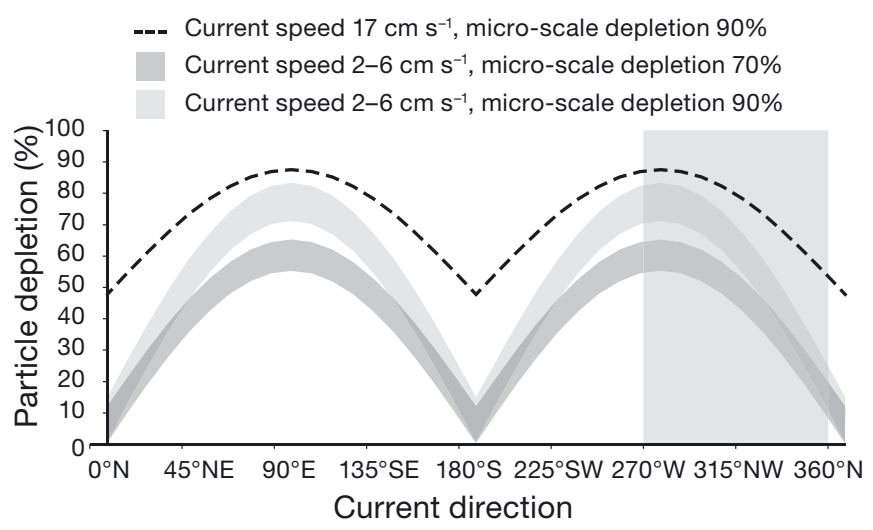

Fig. 10. Particle depletion as a function of different current directions. Micro-scale depletion value is percentage of outside chlorophyll concentration. Grey shaded area: the span of current directions during the campaign period

centration) was found with a current velocity of $2 \mathrm{~cm}$ $\mathrm{s}^{-1}$, a current direction of $360^{\circ}(\mathrm{N})$ and a microdepletion of $70 \%$. With $\mathrm{N}-\mathrm{W}$ current directions that most frequently occurred during the campaign period (Fig. 2) and current velocities of 2-6 $\mathrm{cm} \mathrm{s}^{-1}$, modeled depletions ranged between 40 and $80 \%$ of external concentrations (Fig. 10).

\section{DISCUSSION}

This study documented depletion of food (chl a) within a mussel culture unit in reference to external ambient conditions. Depletion ranged from 0 to $40 \%$, reduced relative to external concentrations, and was different between 3 distinct depth layers, delineated by density difference, and was modulated by current velocity in the 2 top layers. Current velocity-dependent seston depletion has been demonstrated in natural benthic populations of mussels, in on-bottom cultivation units (Petersen 2004), and in rafts with suspended mussels (Petersen et al. 2008, Cranford et al. 2014, Newell \& Richardson 2014). Depletion in commercial-scale units (at the unit scale) has not been extensively documented in micro- or low-tidal eutrophic waters, which are currently the typical conditions for the application of mitigation culture. Microtidal estuaries with persistent stratification have been associated with reduced vertical mixinginduced phytoplankton growth (physical control of phytoplankton distribution), and thus higher proportional concentrations of phytoplankton relative to nutrient concentrations (Monbet 1992, Hughes et al. 2011). This is relevant to mitigation culture, as nutrient sources are overwhelmingly diffuse and terres- 
trial, and mussel aggregates are situated in the upper photic zone. This effect can become pronounced as phytoplankton concentrations increase and further reduce the depth of the effective photic zone. The differences in depletion between layers and dependency on current velocity have several explanations. Wind speed is a principal determinant of the depth of the surface layer in the water column; during the campaign period, the depth of this layer varied between 1.3 and $4.7 \mathrm{~m}$ and corresponded proportionally to wind speed. Mussel aggregations were hanging from ca. 1.5-2 m depth, depending on the total mussel biomass and condition of the floats, implying that a minor portion of the top layer was affected by mussel filtration. This can help explain the lower degree of depletion in the top layer compared to the mid-layer. In the lower layer, variation in current velocity was low, mussels did not occupy the entire extension of the layer throughout the culture unit and concentrations of chl a were generally low. At chl a concentrations below ca. $0.5 \mu g \mathrm{~g}^{-1}$, mussels tend to close their valves and reduce filtration (Riisgård et al. 2003). Taking depletion on the micro-scale into account, concentrations may have been $<0.5 \mu \mathrm{g}$ $\mathrm{l}^{-1}$ at several occasions, potentially affecting mussel filtration, and thereby depletion.

The present findings are within the range of food depletion reported in previous studies on in situ depletion in and around mussel culture units, but existing data on depletion are not unambiguous and range from 0 to $80 \%$ reduction of outside concentrations (Perez Camacho et al. 1991, Heasman et al. 1998, Ogilvie et al. 2000, Strohmeier et al. 2005, Cranford et al. 2008, 2014, Petersen et al. 2008, Nielsen et al. 2016, reviewed extensively by Cranford 2019). The implementation of mitigation culture is principally focused in highly eutrophic waters or in recipient waters to point sources as a compensation mechanism. In relation to water velocity, depletion has been demonstrated utilizing similar methods as employed here within raft superstructure cultivation units for Mytilus galloprovincialis in a tidal estuary; however, current velocity did not correlate with depletion rates (Petersen et al. 2008); low chl a concentrations and minimal variation in velocity were cited as plausible contributing factors. Horizontally distributed depletion at the macro-scale and vertically distributed depletion patterns at the meso-scale agree with the present study's findings: enhanced relative depletion in the center of the unit (macro) and mid to lower sections (meso).

Differences in how depletion is measured, type of culture unit (i.e. raft vs. longline), density of ropes, mussel size or filtration capacity, current velocity and phytoplankton concentrations make direct comparisons of depletion rates difficult. In order to detect small, but significant, differences of chl a concentration, either very accurate sampling or generation of a large number of data points are required. In a patchy environment like a coastal water column, sampling procedures are not trivial and may explain why only a few studies have reported depletion in commercial units. Likewise, it can be appreciated that the filtration capacity per area or volume unit will affect depletion (Newell \& Richardson 2014). Quantity and quality of food available to individual mussels, driven by physical and biological factors, in reference to a local system (integrated clearance rate), will describe depletion potential. Hence, density of ropes (Rosland et al. 2011), size of the mussels (Jacobs et al. 2015), water temperature, chlorophyll concentration, and seston composition (Petersen et al. 2008) regulate depletion.

\subsection{Physical drivers of depletion}

The interaction between physical forcing and the culture unit is not straightforward. Water approaching a mussel culture unit will to some extent be deflected to the sides and below the unit and the water passing through the unit will have reduced flow velocities compared to outside the unit (Blanco et al. 1996, Boyd \& Heasman 1998, Plew 2011, Stevens \& Petersen 2011). The deflection of flow and the vortices generated will depend on several factors, like current velocity, submerged orientation of the culture unit facing the flow, density of culture ropes and thickness of the individual ropes. Flow will behave differently when approaching an open longline culture parallel to the orientation of the lines and with wide spacing between the lines than when approaching a dense raft culture. In the first case, a substantial amount of water will be channeled through the unit, with flow disturbance primarily around the individual lines or ropes (Kolmberger 1981), while in the latter case, major flow deflection and generation of turbulence will take place (Blanco et al. 1996, Boyd \& Heasman 1998).

As it is useful to evaluate hydrodynamic interactions with suspended culture systems at multiple scales (Stevens et al. 2008), it follows that characterizing depletion at multiple scales can elucidate interactions within a biophysical domain. In Ljungskile, there was no straightforward relationship between physical forcing, the geometry of the culture unit, 
and level of depletion. Eddies created around the lines may have been small and led to intrusion of water in the perimeter of the unit. Wind action on the surface may also have affected current patterns and especially the depth of the upper layer, but vertical mixing can be considered negligible during the campaign period due to strong stratification, and of only small importance during the entire production period. Previous work has shown that stratified flows in low energy conditions generally lead to horizontal deflection, and limited vertical mixing within the canopy (Plew et al. 2006). Low current velocities and the open structure of the unit combined with moderate-high levels of chl a formed sufficient food flux conditions for uninhibited growth, at least until approaching harvestable size. Optimization and expansion of culture unit design should thus focus on the meso-scale, especially in periods with larger mussels or in sites with lower chlorophyll concentrations in the months before harvest. At the microscale, model scenarios highlight the significance of depletion potentials, which are driven by meso-scale configurations and mussel density (interspecific-integrated pumping). With the siphon mimic sampling technique, we were able to demonstrate depletion where the individual mussel pumps water through the inhalant siphon. Traditional techniques of water sampling or using diver-operated syringes (Heasman et al. 1998) may not sample at the relevant scale or will risk disturbing the sampled water mass and compromise acquisition of representative samples. In this study, an effect of physical forcing was not detected at the micro-scale, likely due to limited sample occasions, trivial difference in forcing, or canopy elementdriven turbulent flow conditions (Plew at al. 2009).

While filtration as a function of hydrodynamics has been studied previously, the present study adds to a paucity of data on spatial food depletion in commercial culture units. Particle capture is a function of morphological-scale dynamics, which are in turn influenced by meso-scale dynamics (Nielsen \& Vismann 2014). In general, increased velocities and Reynolds conditions reduce filtration efficiency, and contrasting conditions generally permit higher efficiencies. Reduced depletion rates in high velocity or turbulent regimes can be attributed to a combinatorial effect of differential pressure between the siphon and high-gradient boundary layer velocity field and increased volumetric renewal rate (Saurel et al. 2013). However, extremes in current velocities are typically taken into account when siting aquaculture; moderate differences in velocity tend to be of interest when describing depletion. Higher moderate veloci- ties increase flushing/renewal rates within the unit, providing greater homogeneity in growth across the unit, while reduced velocities maximize growth at the edge and tend to exhibit pronounced depletion in the center or predominant downstream orientation of the unit (Stevens \& Petersen 2011, Newell \& Richardson 2014). Leveraging hydrodynamic regimes to optimize phytoplankton residence times within cultivation units, and maximizing depletion potential, may present opportunities for increased nutrient extraction and water column transparency.

\subsection{Mussel growth}

Mussel growth measured in this study is comparable to or higher than growth measured in a close-by area (Loo \& Rosenberg 1983) or at similar study sites (Mallet \& Carver 1991, Karayücel \& Karayücel 2000, Garen et al. 2004). In the final part of the production period, a significantly reduced mean dry weight in the middle of the unit compared to the outer longlines could be observed, which is likely due to food depletion and limitation. With a longer production period, where mussels are grown to a greater size for human consumption, the effect of phytoplankton depletion on growth/size would be expected to become more pronounced. This corresponds with observations of reduced marketable production in culture units with high density compared to low density (Heasman et al. 1998, Cubillo et al. 2012) and with reduced meat content in mussels in the center of a longline unit compared to the perimeter (Strohmeier et al. 2005).

There was no reduced growth in the bottom layer, despite the fact that chlorophyll concentrations present during the production period were lowest at the bottom part of the culture unit. Provided higher current velocities in the lower layer, entrainment into the canopy at lower levels could renew food resources at a rate exceeding consumption (Stevens \& Petersen 2011). In general, levels of chl a were sufficient throughout the production period and only in the very last phase of the production period did concentrations fall below ca. $2 \mu \mathrm{g} \mathrm{l}^{-1}$. Factors other than food flux can influence growth, e.g. disturbance and predation. In the surface layer, wave action on the mussel bands can disrupt the structural integrity of a mussel aggregation, directing energy use to reorganization (Young 1985, Mallet \& Carver 1991, Carrington et al. 2015), thereby affecting the integrated available feeding time and energy utilization for the mussels. This is correlated with the observation in 
this study of more pronounced differences in length along the horizontal axis in the narrow upper layers.

In mitigation culture, where mussels are generally smaller than in traditional modes, are more heterogeneous in size, are in higher densities, and harvested sooner, depletion-related growth patterns (spatial dependence) may be difficult to distinguish from other factors if distributed randomly. Growth patterns that are autocorrelated or simply observable in parts of the unit where the highest degree of depletion can be measured will be informative for farm management, reconfiguration, and expansion. While it is expected that depletion-related growth differences will be present in mitigation units, characterizing patterns of depletion can drive harvest strategies. While we do not explore modified harvest strategies here, this approach could be further developed to evaluate whether partial harvests in different parts of the farm and permitting on-growth of persistently depleted sections would be advantageous over single harvests.

\subsection{Simple model application}

In this study, micro-scale depletion refers directly to filtration pressure around the substrate and is a function of mussel size and density. The meso-scale is described in terms of the structural orientation and configuration of the farm, while the macro-scale places the farm as a feature of the larger cultivation area. Interactions between scales is examined by coupling the 'depletion scales' in a simple manner. The mean chl a concentration throughout the monitoring period at $1.5 \mathrm{~m}$ depth outside the culture unit was $4.6 \mu \mathrm{g} \mathrm{l}^{-1}$, and at $7 \mathrm{~m}$ was $2.5 \mu \mathrm{g} \mathrm{l}^{-1}$ during the extent of the monitoring period. Mean summerautumn concentrations at $1.5 \mathrm{~m}$ were above $6 \mu \mathrm{g} \mathrm{l} \mathrm{l}^{-1}$, exceeding $10 \mathrm{\mu g} \mathrm{l}^{-1}$ in several weeks, while late autumn-early spring concentrations were $3.4 \mu \mathrm{g} \mathrm{l}^{-1}$. Maintenance concentration of food or the 0-growth concentration is around $0.8 \mu \mathrm{g} \mathrm{l}^{-1}$ in mussels (Riisgård 1991, Clausen \& Riisgård 1996, Petersen et al. 1997). Allowing for micro-scale depletion, a concentration in the center of the culture of no less than $1.3 \mu \mathrm{g} \mathrm{l}^{-1}$ can then be assumed as necessary for growth, thus allowing for depletion to the center of the unit of $56 \%$ of the outside concentration. Model runs on this assumption (using a current velocity of $6 \mathrm{~cm} \mathrm{~s}^{-1}$ and a micro-scale depletion of $90 \%$ ) determine a maximum number of longlines with a perpendicular current direction of 25 lines (tiers), which corresponds to 2.5 culture units under the present configuration. If the current direction is parallel to the long axis of the unit, the number of possible cultivation lines (tiers) will be 80 , which corresponds to 0.14 culture units. Similar calculations for the top layer allow for a reduction of $30 \%$ and thus 58 lines (tiers) with a perpendicular current, corresponding to 5.8 culture units, and 185 lines or 0.31 culture units with a parallel current direction.

Orientation of culture units to the main current direction is important to production characteristics and depletion potential. The span of current directions during the investigation period (in situ measurements) was between $270^{\circ} \mathrm{W}$ and $0^{\circ} \mathrm{N}$. Using an angle of $270-300^{\circ} \mathrm{W}$ for the current direction into the culture unit and a micro-scale depletion of $90 \%$, depletion with a current speed of $2 \mathrm{~cm} \mathrm{~s}^{-1}$ is modeled to be about $65 \%$ of ambient conditions and with a current speed of $6 \mathrm{~cm} \mathrm{~s}^{-1}$ to be $80 \%$ (Fig. 9). These values correspond well with the measured values in situ for the mid-layer (Fig. 5) with about 65-90\% depletion. Measured depletion was in general lower than modeled depletion. The applied model is rather crude and a number of its assumptions are clearly not valid (i.e. laminar flow regimes). Thus, if flow through the unit is not laminar and the mussels are not evenly suspended, there will not be equivalent access to homogeneous food concentrations, which will affect levels of depletion. Flow retardation will lead to increased turbulence levels and to intrusion of water from the sides and from below the unit, thereby potentially increasing food availability. Uneven distribution of mussels will also result in lower particle retention than evenly distributed mussels with full access to a hypothetically homogeneous phytoplankton community. Both assumptions will result in higher depletion than would be expected and measured. The model is, however, simple and has very few input requirements. Complex $2 \mathrm{D}$ and 3D model setups can be employed, but they will be dependent on more input data, such as exact measurements of dispersion coefficients (Pilditch et al. 2001) that often are not available.

\subsection{Production considerations of mitigation cultures}

Depletion in terms of production is generally a function of space limitation, thus maximizing yield from a given area is prioritized. This is all the more relevant for mitigation farming, where maximizing seston assimilation and immobilization are prioritized. Depletion in terms of shifts in phytoplankton community 
compositions may influence local ecology (e.g. Cranford et al. 2008, Froján et al. 2018). Size fractionation from mussel filtration/feeding and refiltration can broaden ecological space for smaller phytoplankton taxa, such as picophytoplankton, which can dominate phytoplankton biomass in heavily grazed waters. The ramifications of depletion-induced plankton community shifts requires further investigation, particularly if total food sources are diminished due to particle size-limited clearance. On the other hand, there is evidence that effective retention of smaller particles can be realized under oligotrophic (Strohmeier et al. 2012) or extensively cultured waters (Sonier et al. 2016), which would indicate that there is variability in adaptive feeding responses of mussels in field conditions. While the overabundance of phytoplankton in eutrophic waters is a key factor to address in the implementation of mitigation cultures, monitoring depletion by plankton or seston size fraction may further detail mitigation effects and ecological ramifications of mitigation culture.

Investigation of depletion at multiple scales can better describe the ecological impacts of mitigation cultivation practices or strategies. At the basin scale, there have been efforts to characterize bivalve culture depletion impacts on phytoplankton abundance with airborne spectral remote sensing (Grant et al. 2007) and satellite remote sensing (Gernez et al. 2017). Coupling analytical scales as performed in this study with basin-scale analysis could enhance precision in estimates of depletion, as well as help resolve competing effects, such as wind-driven advection, baroclinic advection, or vertical dispersion further afield (Fréchette 2010).

\section{CONCLUSION}

In summary, depletion of food in a longline mitigation unit will depend on current velocity, current direction and geometry of the unit in relation to predominant flow direction. In areas with more pronounced tidal flows, geometry and orientation are important parameters for optimization. In a nutrient-rich environment, high ambient food concentrations may compensate for depletion, even in a low current environment, but in mussels reaching a larger size class, this did not compensate for depletion and reduced growth was observed. In areas with little available hydrographical information, simple models are a useful tool for design of culture units and calculations of carrying capacity. It can be beneficial to the nascent mitigation culture industry that design, geometry, and ori- entation of a culture unit is evaluated before establishment of a unit. This approach is not exclusive of traditional cultivation methods; however, it can be instrumental for pragmatic proliferation and assessment of mitigation culture in low-tidal, stratified conditions that make up many eutrophic coastal waters. Future investigations pairing depletion and mitigation cultures may be able to leverage seasonal growth data (energetics) to determine optimal harvest strategies for maximum nutrient extraction. Characterizing depletion patterns, and the scales at where they overlap, can be a helpful instrument to evaluate positive and negative ecosystem-scale interactions of mitigation culture in regards to local conditions. It is expected that data on culture configuration strategies and concomitant mass balances in a 'nutrient shed' will help direct management of coastal waters utilizing mitigation cultivation practices as an integral mechanism to address eutrophication.

Acknowledgements. We thank Jens Larsen and Peter Dahl for indispensable assistance in carrying out sampling and measurements. We are also grateful to Scanfjord, who allowed us to use one of their culture units as our study object. We thank the editor, Gianluca Sará, and 3 anonymous reviewers for their constructive feedback and suggestions, which have enhanced the manuscript. This work was supported by EU ESSENSE contract no. FAIR-CT98-4201.

\section{LITERATURE CITED}

Beadman HA, Willows RI, Kaiser MJ (2002) Potential applications of mussel modelling. Helgol Mar Res 56:76-85

Bivand RS, Wong DWS (2018) Comparing implementations of global and local indicators of spatial association. Test 27:716-748

Björk G, Ljungman O, Rydberg L (2000) Net circulation and salinity variations in an open-ended Swedish fjord system. Estuaries 23:367-380

Blanco J, Zapata M, Moroño A (1996) Some aspects of the water flow through mussel rafts. Sci Mar 60:275-282

Boesch DF (2002) Challenges and opportunities for science in reducing nutrient over-enrichment of coastal ecosystems. Estuaries 25:886-900

Boyd AJ, Heasman KG (1998) Shellfish mariculture in the Benguela System: water flow patterns within a mussel farm in Saldanha Bay, South Africa. J Shellfish Res 17: $25-32$

Carrington E, Waite JH, Sarà G, Sebens KP (2015) Mussels as a model system for integrative ecomechanics. Annu Rev Mar Sci 7:443-469

Clausen I, Riisgård HU (1996) Growth, filtration and respiration in the mussel Mytilus edulis: no evidence for physiological regulation of the filter-pump to nutritional needs. Mar Ecol Prog Ser 141:37-45

Cottrell RS, Fleming A, Fulton EA, Nash KL, Watson RA, Blanchard JL (2018) Considering land-sea interactions and trade-offs for food and biodiversity. Glob Change 
Biol 24:580-596

Cranford PJ (2019) Magnitude and extent of water clarification services provided by bivalve suspension feeding. In: Smaal A, Ferreira J, Grant J, Petersen J, Strand Ø (eds) Goods and services of marine bivalves. Springer, Cham, p 119-142

Cranford PJ, Li W, Strand Ø, Strohmeier T (2008) Phytoplankton depletion by mussel aquaculture: high resolution mapping, ecosystem modeling and potential indicators of ecological carrying capacity. ICES CM Doc 2008/H:12. International Council for the Exploration of the Sea, Copenhagen. http://ices.dk/sites/pub/CM\%20 Doccuments/CM-2008/H/H1208.pdf

* Cranford PJ, Duarte P, Robinson SMC, Fernández-Reiriz MJ, Labarta U (2014) Suspended particulate matter depletion and flow modification inside mussel (Mytilus galloprovincialis) culture rafts in the Ría de Betanzos, Spain. J Exp Mar Biol Ecol 452:70-81

Cubillo AM, Peteiro LG, Fernández-Reiriz MJ, Labarta U (2012) Influence of stocking density on growth of mussels (Mytilus galloprovincialis) in suspended culture. Aquaculture 342-343:103-111

Danmarks Folketinget (2016) Lovforslag nr. L 111: Forslag til lov om ændring af lov om miljøbeskyttelse (kompenserende marine virkemidler ved etablering eller udvidelse af havbrug). Danish Parliament, Copenhagen. www.folket ingstidende.dk/RIpdf/samling/20161/lovforslag/L111/ 20161_L111_som_fremsat.pdf

Diaz R, Selman M, Chique C (2011) Eutrophication and hypoxia: nutrient pollution in coastal waters. World Resources Institute, Washington, DC. www.wri.org/resources/ data-sets/eutrophication-hypoxia-map-data-set

European Environment Agency (EEA) (2018) European waters: assessment of status and pressures 2018. EEA Rep No. 7/2018. Publications Office of the European Union, Luxembourg

Ferreira JG, Bricker SB (2016) Goods and services of extensive aquaculture: shellfish culture and nutrient trading. Aquacult Int 24:803-825

Ferreira JG, Andersen JH, Borja A, Bricker SB and others (2011) Overview of eutrophication indicators to assess environmental status within the European Marine Strategy Framework Directive. Estuar Coast Shelf Sci 93: $117-131$

Fréchette M (2010) Hierarchical structure of bivalve culture systems and optimal stocking density. Aquacult Int 18: 99-114

Froján M, Castro CG, Zúñiga D, Arbones B, Alonso-Pérez F, Figueiras FG (2018) Mussel farming impact on pelagic production and respiration rates in a coastal upwelling embayment (Ría de Vigo, NW Spain). Estuar Coast Shelf Sci 204:130-139

Garen P, Robert S, Bougrier S (2004) Comparison of growth of mussel, Mytilus edulis, on longline, pole and bottom culture sites in the Pertuis Breton, France. Aquaculture 232:511-524

Gernez P, Doxaran D, Barillé L (2017) Shellfish aquaculture from space: potential of Sentinel2 to monitor tide-driven changes in turbidity, chlorophyll concentration and oyster physiological response at the scale of an oyster farm. Front Mar Sci 4:137

Grant J, Stenton DJ, Monteiro P, Pitcher G, Heasman K (1998) Shellfish culture in the Benguela system: a carbon budget of Saldanha Bay for raft culture of Mytilus galloprovincialis. J Shellfish Res 17:41-49
Grant J, Bugden G, Horne E, Archambault MC, Carreau M (2007) Remote sensing of particle depletion by coastal suspension-feeders. Can J Fish Aquat Sci 64:387-390

*Gren IM, Lindahl O, Lindqvist M (2009) Values of mussel farming for combating eutrophication: an application to the Baltic Sea. Ecol Eng 35:935-945

Haamer J (1997) The mussel industry of Sweden. NOAA Tech Rep NMFS 129:1-6

Heasman KG, Pitcher GC, McQuaid CD, Hecht T (1998) Shellfish mariculture in the Benguela system: raft culture of Mytilus galloprovincialis and the effect of rope spacing on food extraction, growth rate, production, and condition of mussels. J Shellfish Res 17:33-39

Holm-Hansen O, Lorenzen CJ, Holmes RW, Strickland JDH (1965) Fluorometric determination of chlorophyll. ICES J Mar Sci 30:3-15

* Hughes BB, Haskins JC, Wasson K, Watson E (2011) Identifying factors that influence expression of eutrophication in a central California estuary. Mar Ecol Prog Ser 439: $31-43$

* Ibarra DA, Cembella A, Grant J (2012) Attenuation of sunlight measured from moored radiometers to assess depletion of suspended particles caused by bivalve aquaculture. Limnol Oceanogr Methods 10:1051-1069

Incze LS, Lutz RA (1980) Mussel culture: an east coast perspective. In: Lutz RA (ed) Mussel culture and harvest: a North American perspective. Elsevier, Amsterdam, p 99-140

Incze LS, Lutz RA, True E (1981) Modelling carrying capacities for bivalve molluscs in open, suspended-culture systems. J World Maricult Soc 12:143-155

* Jacobs P, Troost K, Riegman R, van der Meer J (2015) Length- and weight-dependent clearance rates of juvenile mussels (Mytilus edulis) on various planktonic prey items. Helgol Mar Res 69:101-112

Karayücel S, Karayücel I (2000) The effect of environmental factors, depth and position on the growth and mortality of raft-cultured blue mussels (Mytilus edulis L.). Aquacult Res 31:893-899

Kolmberger B (1981) Strömförhållanden i musselodlingar laboratorieförsök. MSc thesis, Chalmers Tekniska Högskola, Göteborg. www.miljomusslor.loven.gu.se/pdf/ Kolmberger1981.pdf

KLoo LO, Rosenberg R (1983) Mytilus edulis culture: growth and production in western Sweden. Aquaculture 35: $137-150$

Mallet AL, Carver CE (1991) An assessment of strategies for growing mussels in suspended culture. J Shellfish Res 10:471-477

* Monbet Y (1992) Control of phytoplankton biomass in estuaries: a comparative analysis of microtidal and macrotidal estuaries. Estuaries 15:563-571

Moran P (1950) Notes on continuous stochastic phenomena. Biometrika 37:17-23

* Newell C, Richardson J (2014) The effects of ambient and aquaculture structure hydrodynamics on the food supply and demand of mussel rafts. J Shellfish Res 33:257-272

*Nielsen P, Vismann B (2014) Clearance rate of Mytilus edulis (L.) as a function of current velocity and mussel aggregation. J Shellfish Res 33:457-463

* Nielsen P, Cranford PJ, Maar M, Petersen JK (2016) Magnitude, spatial scale and optimization of ecosystem services from a nutrient extraction mussel farm in the eutrophic Skive Fjord, Denmark. Aquacult Environ Interact 8: 311-329 
O'Donncha F, Hartnett M, Nash S (2013) Physical and numerical investigation of the hydrodynamic implications of aquaculture farms. Aquacult Eng 52:14-26

Officer C, Smayda T, Mann R (1982) Benthic filter feeding: a natural eutrophication control. Mar Ecol Prog Ser 9: 203-210

Ogilvie SC, Ross AH, Schiel DR (2000) Phytoplankton biomass associated with mussel farms in Beatrix Bay, New Zealand. Aquaculture 181:71-80

* Ord JK, Getis A (1995) Local spatial autocorrelation statistics: distributional issues and an application. Geogr Anal 27:286-306

Paerl HW (2009) Controlling eutrophication along the freshwater-marine continuum: dual nutrient ( $\mathrm{N}$ and $\mathrm{P}$ ) reductions are essential. Estuar Coasts 32:593-601

Penney RW, McKenzie CH, Mills TJ (2001) Assessment of the particulate food supply available for mussel (Mytilus spp.) farming in a semi-enclosed, northern inlet. Estuar Coast Shelf Sci 53:107-121

Perez Camacho A, Gonzalez R, Fuentes J (1991) Mussel culture in Galicia (NW Spain). Aquaculture 94:263-278

Petersen JK (2004) Grazing on pelagic primary producers the role of benthic suspension feeders in estuaries. In: Nielsen, SL, Banta, GT, Pedersen, MF (eds) Estuarine nutrient cycling: the influence of primary producers. Kluwer, Dordrecht, p 129-152

Petersen JK, Schou O, Thor P (1997) In situ growth of the ascidian Ciona intestinalis (L.) and the blue mussel Mytilus edulis in an eelgrass meadow. J Exp Mar Biol Ecol 218:1-11

Petersen JK, Bougrier S, Smaal AC, Garen P, Robert S, Larsen JEN, Brummelhuis E (2004) Intercalibration of mussel Mytilus edulis clearance rate measurements. Mar Ecol Prog Ser 267:187-194

Petersen JK, Nielsen TG, van Duren L, Maar M (2008) Depletion of plankton in a raft culture of Mytilus galloprovincialis in Ría de Vigo, NW Spain. I. Phytoplankton. Aquat Biol 4:113-125

Petersen JK, Hasler B, Timmermann K, Nielsen P, Tørring DB, Larsen MM, Holmer M (2014) Mussels as a tool for mitigation of nutrients in the marine environment. Mar Pollut Bull 82:137-143

Petersen JK, Saurel C, Nielsen P, Timmermann K (2016) The use of shellfish for eutrophication control. Aquacult Int 24:857-878

* Petersen JK, Holmer M, Termansen M, Hasler B (2019) Nutrient extraction through bivalves. In: Smaal A, Ferreira J, Grant J, Petersen J, Strand Ø (eds) Goods and services of marine bivalves. Springer, Cham, p 179-208

* Pilditch CA, Grant J, Bryan KR (2001) Seston supply to sea scallops (Placopecten magellanicus) in suspended culture. Can J Fish Aquat Sci 58:241-253

Plew DR (2011) Depth-averaged drag coefficient for modeling flow through suspended canopies. J Hydraul Eng 137:234-247

Plew DR, Spigel RH, Stevens CL, Nokes RI, Davidson MJ (2006) Stratified flow interactions with a suspended canopy. Environ Fluid Mech 6:519-539

Plew DR, Enright MP, Nokes RI, Dumas JK (2009) Effect of mussel bio-pumping on the drag on and flow around a mussel crop rope. Aquacult Eng 40:55-61
R Core Team (2017) R: a language and environment for statistical computing. R Foundation for Statistical Computing, Vienna

* Rabalais NN, Turner RE, Díaz RJ, Justi D (2009) Global change and eutrophication of coastal waters. ICES J Mar Sci 66:1528-1537

Riisgård HU (1991) Filtration rate and growth in the blue mussel, Mytilus edulis Linneaus: dependence on algal concentration. J Shellfish Res 10:29-35

Riisgård HU (2001) On measurement of filtration rates in bivalves - the stony road to reliable data: review and interpretation. Mar Ecol Prog Ser 211:275-291

Kiisgård HU, Kittner C, Seerup DF (2003) Regulation of opening state and filtration rate in filter-feeding bivalves (Cardium edule, Mytilus edulis, Mya arenaria) in response to low algal concentration. J Exp Mar Biol Ecol 284:105-127

Kodhouse PG, Roden CM (1987) Carbon budget for a coastal inlet in relation to intensive cultivation of suspensionfeeding bivalve molluscs. Mar Ecol Prog Ser 36:225-236

Kose JM, Bricker SB, Tedesco MA, Wikfors GH (2014) A role for shellfish aquaculture in coastal nitrogen management. Environ Sci Technol 48:2519-2525

* Rosland R, Bacher C, Strand Ø, Aure J, Strohmeier T (2011) Modelling growth variability in longline mussel farms as a function of stocking density and farm design. J Sea Res 66:318-330

* Sarà G, Martire ML, Sanfilippo M, Pulicanò G and others (2011) Impacts of marine aquaculture at large spatial scales: evidences from $\mathrm{N}$ and $\mathrm{P}$ catchment loading and phytoplankton biomass. Mar Environ Res 71:317-324

Saurel C, Petersen JK, Wiles PJ, Kaiser MJ (2013) Turbulent mixing limits mussel feeding: direct estimates of feeding rate and vertical diffusivity. Mar Ecol Prog Ser 485: $105-121$

Savage C, Leavitt PR, Elmgren R (2010) Effects of land use, urbanization, and climate variability on coastal eutrophication in the Baltic Sea. Limnol Oceanogr 55:1033-1046

Schröder T, Stank J, Schernewski G, Krost P (2014) The impact of a mussel farm on water transparency in the Kiel Fjord. Ocean Coast Manage 101:42-52

* Sonier R, Filgueira R, Guyondet T, Tremblay R and others (2016) Picophytoplankton contribution to Mytilus edulis growth in an intensive culture environment. Mar Biol 163:73

* Stevens CL, Petersen JK (2011) Turbulent, stratified flow through a suspended shellfish canopy: implications for mussel farm design. Aquacult Environ Interact 2:87-104

* Stevens C, Plew D, Hartstein N, Fredriksson D (2008) The physics of open-water shellfish aquaculture. Aquacult Eng 38:145-160

Strohmeier T, Aure J, Duinker A, Castberg T, Svardal A, Strand $\varnothing$ (2005) Flow reduction, seston depletion, meat content and distribution of diarrhetic shellfish toxins in a long-line blue mussel (Mytilus edulis) farm. J Shellfish Res 24:15-23

Strohmeier T, Strand Ø, Alunno-Bruscia M, Duinker A, Cranford PJ (2012) Variability in particle retention efficiency by the mussel Mytilus edulis. J Exp Mar Biol Ecol 412:96-102

* Young GA (1985) Byssus-thread formation by the mussel Mytilus edulis: effects of environmental factors. Mar Ecol Prog Ser 24:261-271

Submitted: August 7, 2018; Accepted: April 22, 2019 Proofs received from author(s): June 17, 2019 